\title{
The Effect of Mergers on Financial Performance PT. Bank Woori Saudara Indonesia 1906, Tbk
}

\author{
Irna Maulana ${ }^{1}$, Gemala Paramita ${ }^{2}$, Syahiruddin ${ }^{3}$ \\ ${ }^{1}$ Financial Management Of Ibn Chaldun University, Jakarta \\ ${ }^{23}$ Fakultas Ekonomi Universitas Ibn Chaldun, Jakarta \\ Correspondence: irnamaulana40@gmail.com
}

Submitted: 3 August 2019. Revised: 27 August, 15 Sept 2019. Published: 30 October 2019.

\begin{abstract}
The Mergers are carried out by the companies to get a number of benefits. Mutually beneficial conditions will occur if the merger activities carried out can create the synergy, which finally, it is expected to improve the company's performance. This study aims to determine whether the financial performance after the merger has changed or not. The financial ratios studied are financial ratios four years after the merger and before the merger. This research was conducted by quantitative methods, by taking data from PT. Bank Woori Saudara Indonesia 1906, Tbk, which has merged in 2014 and has engaged in banking financial services. Sampling in this study uses quota sampling. the data is obtained from one bank, that is, a bank which has merged. The parametric test used to answer the hypothesis in this study was the Paired Sample T-Test. The results of this study indicate that in partial testing of the seven financial ratios, there was a significant difference in the ratio of BR and EPS, while the CAR, TATO, NPM, ROI, and ROE ratios showed no significant differences. So the merger process carried out by banks does not show a significant difference because the synergy has not yet been achieved after the merger.

Keywords: Banking Ratio, Capital Adequacy Ratio, Total Assets Turnover, Net Profit Margin, Return On Investment, Return On Equity, Earning Per Share
\end{abstract}

\section{INTRODUCTION}

In this globalization era, the rate of business growth has greatly increased, this is marked by the development of the various fields, namely communication and technology. With the development of these fields, many large companies make efforts to improve efficiency, performance and competitiveness. To be able to realize it all, the companies usually do a reduction in costs but not to the point of decreasing the company's revenue. However, because the competition faced by the companies is increasingly difficult in this globalization era, then this method is not enough to be able to increase company profits. The Companies must have other strategies in order to survive in business competition in this globalization era.

One of these strategies can be in the form of a business combination between two or more companies. This merger can be carried out by similar and non-similar companies. Many companies do this strategy to avoid an unhealthy business competition and mutually harm one company to another. Besides that, business combination is considered as one of the company's strategies to develop its business in the midst of tight business in the free market era.

The Business combinations can be done by mergers, acquisitions and consolidations. The definition of merger is a combination of two business entities, one business entity still exists, 
and the other one or the other is dissolved legally, and the name of the company used is a wellknown company (Tarigan \& Pratomo, 2015). An acquisition is a company purchase by another company, whether done in cash or paid using the shares of the company that bought it (Heykal \& Hennisia, 2015). While the consolidation is a merger of two or more companies, where all the names of these companies will disappear and the new company names was appear (Juniarti, 2001). From the three ways of business combination, one of the most chosen by companies is to do a merger. Because doing a merger can improve company performance.

Through mergers, the companies can also increase their company value without having to create their own business units. The same is true for the banks, but for banks, in addition to increasing the company value, the banks have other interests by merging. The Bank's interest is to increase its capital, because banks are required to meet the capital adequacy ratio (CAR) set by Bank Indonesia (Sofyan, 2019).

Because the banking industry is one of the sources of Indonesia's economic income, it is necessary for encouragement to strengthen the banks, one of the efforts is by conducting a merger, so that a strong bank with a good bank performance can be expected. And it is better if in Indonesia, the number of banks is small, but the assets of these banks are very large, so that finally, it can bring Indonesian banks to the same rank as international banks. With more and more large banks conducting mergers, it will be easier to access the scope of the International World, so that the mergers will benefit the national economy in general, and the banking world in particular.

The results of previous studies, states that the finding of this study shows that there is no improvement in surviving Company's return on equity, net profit margin, interest coverage, earning per share and dividend per share post-merger \& acquisition (Mahesh \& Prasad, 2012). The financial performance of RBS in the areas of profitability, liquidity, assets management, leverage, and cash flows has been quite satisfactory before the merger deal. It means that merger deal fails to improve the financial performance of the bank (Kemal, 2011). The mergers and acquisition impact profitability of the company and enlarge their market share. Moreover, these mergers and acquisitions improve the value of the stockholders' through raising the demand dividends in the market stock (Yanan, Hamza, \& Basit, 2016).

The financial performance of banking sector of Pakistan in the capacities of profitability, and leverage, has been quite satisfactory before the merger deal. It means that merger deal fails to improve the financial performance of the bank, and banks merge with other small or equal size banks only to capture market share, to open Islamic window, for cost-cutting, to create synergy, to gain efficient resources and to unlock hidden values (Ahmed, Manwani, \& Ahmed, 2018)

\section{METHOD}

The subjects studied in this study were the financial performance of PT. Bank Woori Saudara Indonesia 1906, Tbk (Bank Woori Saudara) by analyzing financial ratios, ie banking ratio, capital adequacy ratio, total aset turnover ratio, net profit margin, return on investment, return on equity, dan earnings per share.

This research uses a descriptive quantitative approach. Descriptive quantitative approach is a conscious and systematic effort to provide the answers to a problem, or to obtain a deeper and broader information about a phenomenon, using stages of research and quantitative approaches. 
The researcher chose PT. Bank Woori Saudara Indonesia 1906, Tbk as the object of research, because the bank is an object in accordance with what the researcher wants to study, which is one of the companies that conducts a merger. This research was conducted in 5 months, starting from March to August 2019. The population used was companies that merged in 2014 which were listed on the Indonesia Stock Exchange (ISE). The sample is PT. Bank Woori Saudara Indonesia 1906, Tbk.

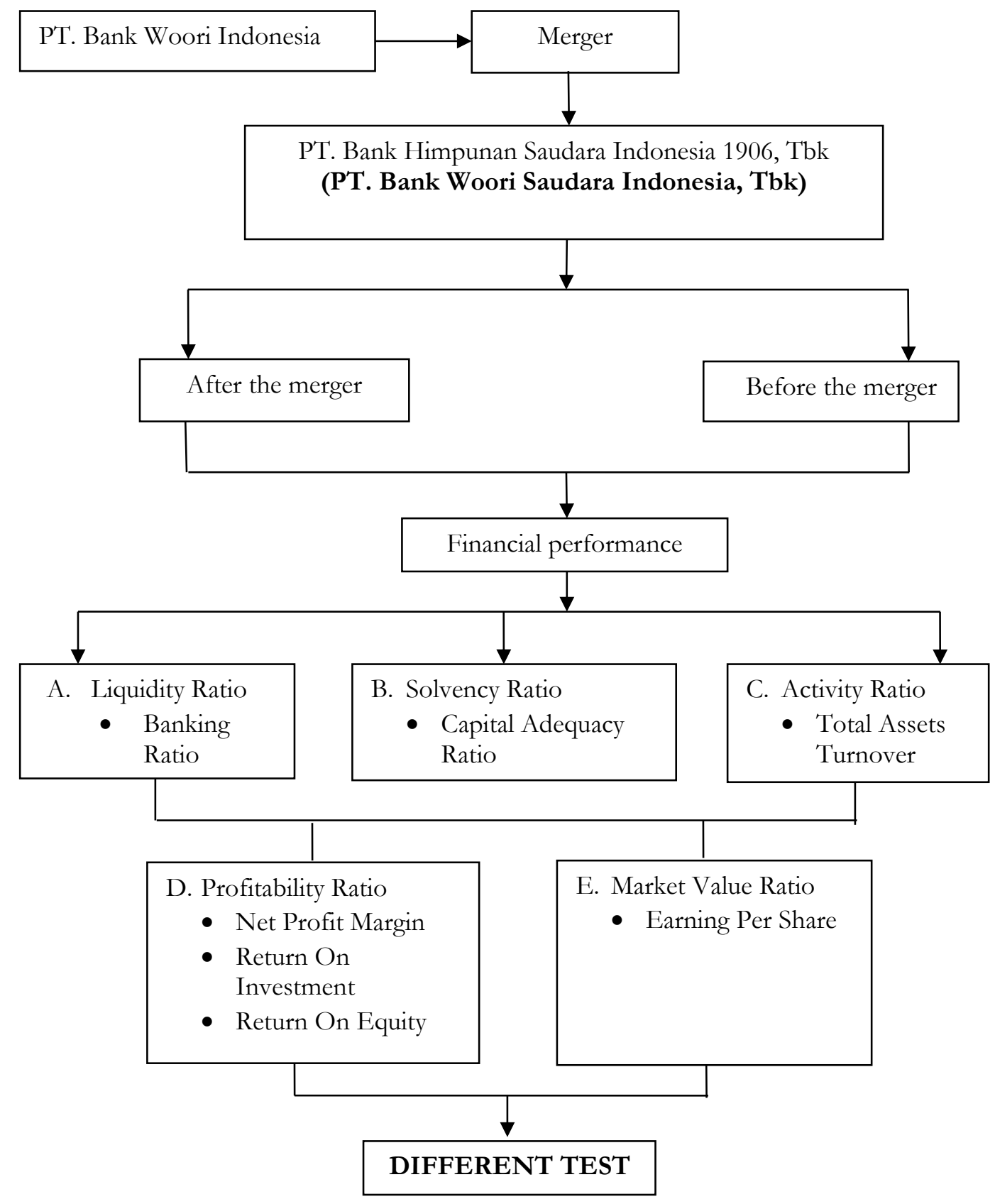

The purpose of this study is to determine the financial performance of PT Bank Woori Saudara Indonesia 1906, Tbk after and before the merger and to know clearly the differences that occur from the financial performance of PT Bank Woori Saudara Indonesia 1906, Tbk after and before the merger. 
The Effect of Mergers on Financial Performance PT. Bank Woori Saudara Indonesia 1906, Tbk

Maulana, Paramita, Syahiruddin

\section{RESULT AND DISCUSSION}

Table 1. Paired sample t-test results before and after the merger

\begin{tabular}{ccccc}
\hline Hypothesis & Variable & Sig. (2-tailed) & $\boldsymbol{\alpha}$ & Conclusion \\
\hline $\mathbf{H}_{\mathbf{a} 1}$ & $\mathrm{BR}$ & 0,024 & 0,05 & Accepted \\
\hline $\mathbf{H a}_{\mathbf{2}}$ & CAR & 0,088 & 0,05 & Rejected \\
\hline $\mathbf{H}_{\mathbf{a} 3}$ & TATO & 0,577 & 0,05 & Rejected \\
\hline $\mathbf{H}_{\mathbf{a} 4}$ & NPM & 0,992 & 0,05 & Rejected \\
\hline $\mathbf{H}_{\mathbf{a} 5}$ & ROI & 0,736 & 0,05 & Rejected \\
$\mathbf{H}_{\mathbf{a} 6}$ & ROE & 0,157 & 0,05 & Rejected \\
\hline $\mathbf{H}_{\mathbf{a} 7}$ & EPS & 0,050 & 0,05 & Accepted \\
\hline
\end{tabular}

\section{Banking Ratio (BR)}

Paired sample t-test results obtained a significance value (Sig. (2-tailed)) of 0.024. Because the significance value is smaller than $0.05(0.024<0.05)$, it means that there is a significant difference in the BR variable with a comparison period of 4 (four) years after with 4 (four) years before the merger.

Based on Bank Indonesia regulations, regarding the ranking of the banking ratio component, the best level of the banking ratio is $75 \%(0.75)$. The results from the banking ratio data of PT. Bank Woori Saudara Indonesia 1906, Tbk, showed that in 2011-2012 was "GOOD". In 2014 the value of the banking ratio was "NOT GOOD", whereas in 2015 the value of the banking ratio was much better than in 2014 which was "ENOUGH". But in 20162018 the value of the banking ratio has decreased again according to BI standards in 2016-2017 was "NOT GOOD" and in 2018 was "VERY NOT GOOD".

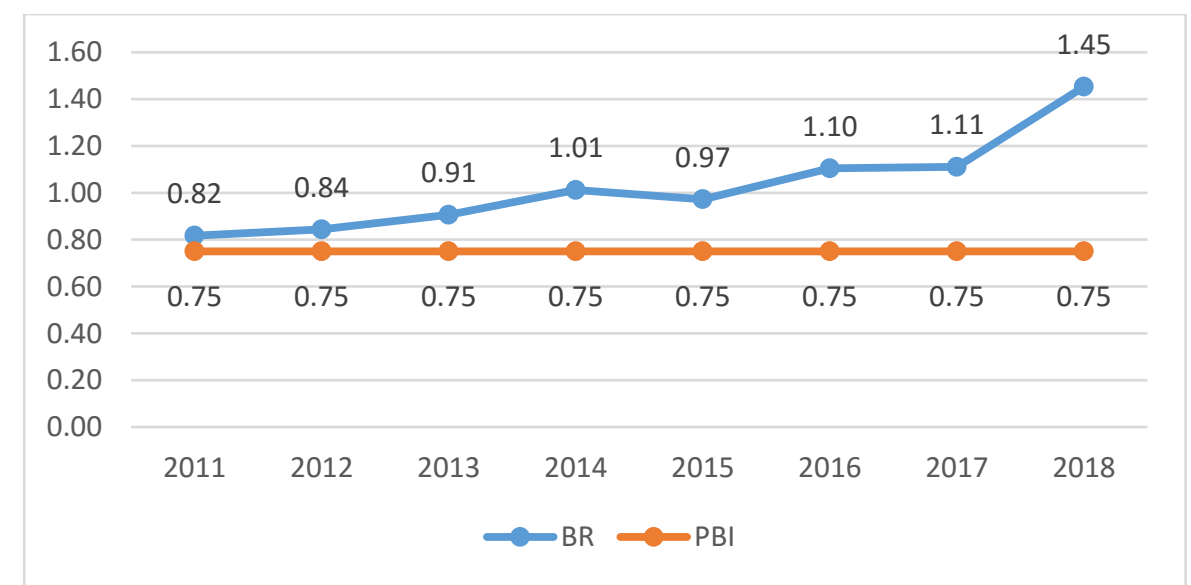

Figure 1. BR of PT. Bank Woori Saudara Indonesia 1906, Tbk (2011-2018) 
These results indicate that the best banking ratio value of PT. Bank Woori Saudara Indonesia 1906, Tbk among the years studied in this study were in 2011-2012. Meanwhile, if seen from the average value, it was obtained that the average of banking ratio before the merger is better than after the merger. The average of banking ratio after the merger is "NOT GOOD" and the average of banking ratio before the merger is "ENOUGH". So the results can be interpreted that before the merger, PT. Bank Woori Saudara Indonesia 1906, Tbk is better able to meet its obligations to pay funds to the customers / depositors for the credit channeled, compared to after the merger. In addition, the results of the study also showed that prior to the merger, the likelihood of lending that was not accompanied by returns or bad loans was smaller, compared to after the merger.

\section{Capital Adequacy Ratio (CAR)}

The capital is the first step that must be prepared by a company to carry out its operational activities. The capital is often a problem for every bank, because it is faced with the risks that are likely to occur (Sofyan, 2019).

Paired sample t-test results showed a significance value (Sig. (2-tailed)) 0.088. Because the significance value is greater than $0.05(0.088>0.05)$, it means that there is no significant difference in the CAR variable in the comparison period 4 (four) years after with 4 (four) years before the merger.

Based on Bank Indonesia regulations regarding the ranking of capital adequacy ratio components, the best level of capital adequacy ratio components is $8 \%(0.08)$. The results of data from the capital adequacy ratio of PT. Bank Woori Saudara Indonesia 1906, Tbk shows that in 2011 was "VERY GOOD", In 2012-2013 it was "GOOD". and in 2014-2018 the value of capital adequacy ratio was "VERY GOOD".

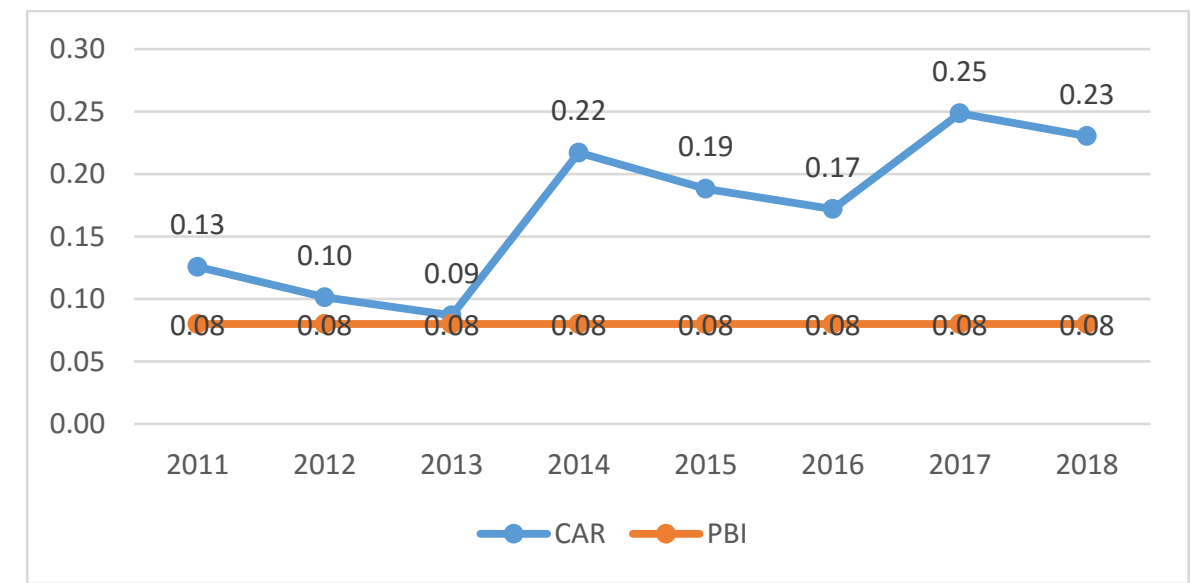

Figure 1. CAR of PT. Bank Woori Saudara Indonesia 1906, Tbk (2011-2018)

The picture above shows that the average capital adequacy ratio after and before the merger is "VERY GOOD". But the capital adequacy ratio after the merger has the largest value of $21 \%$ or 0.21 .

From the results of the average capital adequacy ratio, there is a change in the value of the capital adequacy ratio between after and before the merger. The results of these changes indicate that after the merger, the management of PT. Bank Woori Saudara Indonesia 1906, Tbk is better 
The Effect of Mergers on Financial Performance PT. Bank Woori Saudara Indonesia 1906, Tbk

Maulana, Paramita, Syahiruddin

than before the merger in managing capital adequacy (customer funds) owned for risky activities, such as lending.

\section{Total Assets Turnover (TATO)}

TATO is an indicator used to assess the effectiveness of management in generating sales from invested assets (Duty, 2012). Paired sample t-test results obtained significance value (Sig. (2-tailed)) 0.577. Because the significance value is greater than $0.05(0.577>0.05)$, it means that there is no significant difference in the TATO variable in the comparison period 4 (four) years after with 4 (four) years before the merger.

The results from total assets turnover data of PT. Bank Woori Saudara Indonesia 1906, Tbk shows that in 2011-2013 the value of total assets turnover was not much different, only at the number 0.06, although in 2012 it had decreased. however, the worst decline in total asset turnover occurred in 2014 with a value of 0.01. In 2015-2018 after the merger the total value of assets turnover rose and was in the number 0.04. But if seen from the average total assets turnover, the average after the merger is no better than the average value of total assets turnover before the merger. This happened because the best total asset turnover was in 2011-2013, but that does not mean that after the merger there was no change in the total asset turnover.

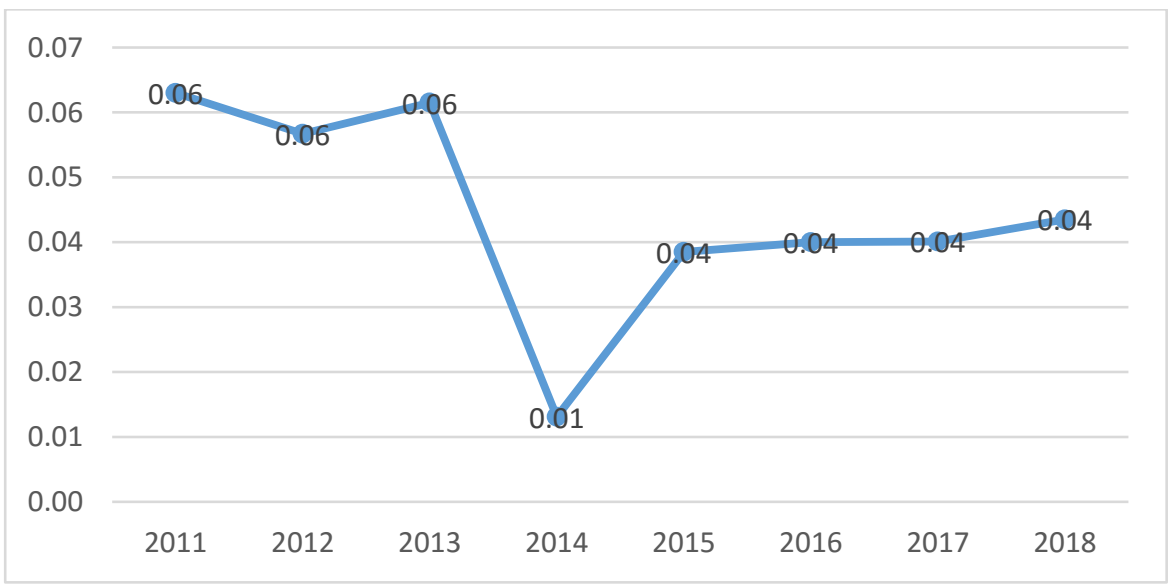

Figure 2. TATO of PT. Bank Woori Saudara Indonesia 1906, Tbk (2011-2018)

The picture above shows that in 2014 , the value of total assets turnover decreased very large, and after the merger the value of total asset turnover increased again every year, although the results of the increase were not as much as in 2011-2013. this means that there are changes that occur after the merger. and after the merger, PT. Bank Woori Saudara Indonesia 1906, Tbk can contribute better in conducting sales activities using assets owned, compared to before the merger.

\section{Net Profit Margin (NPM)}

The greater the ratio of net profit margin, the better for being role in the company's ability to profit quite high (Heikal, Khaddafi, \& Ummah, 2014). Paired sample t-test results showed a significance value (Sig. (2-tailed)) of 0.992. Because the significance value is greater than 0.05 (0.992> 0.05), it means that there is no significant difference in the NPM variable with a comparison period of 4 (four) years after with 4 (four) years before the merger. 
Based on the results of PT. Bank Woori Saudara Indonesia 1906, Tbk, in 2011-2013 the value of net profit margins decreased from 15\% (0.15) to 12\% (0.12). In 2014 the value of net profit margins increased by $32 \%$ (0.32). But after the merger was conducted, the value of net profit margin in 2015-2016 decreased again to 15\% (0.15). However, the value of net profit margin after the merger did not decrease continuously. In 2017-2018, the value of net profit margin increased from the previous year, which was $20 \%-22 \%(0.20-0.22)$.

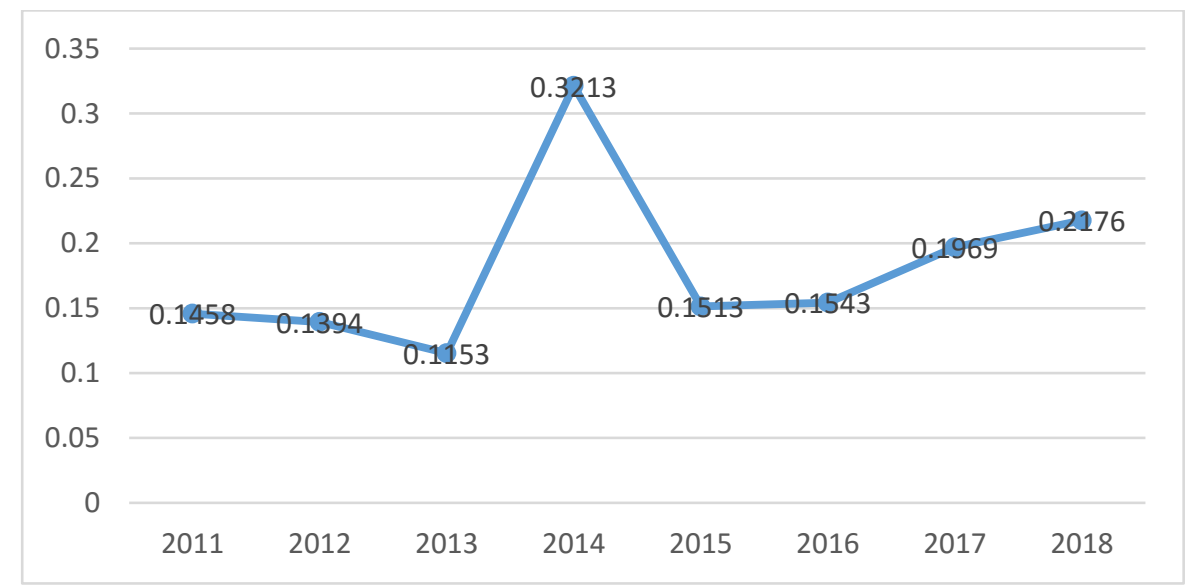

Figure 3. NPM of PT. Bank Woori Saudara Indonesia 1906, Tbk (2011-2018)

If seen from the average value of net profit margin, the average value after and before the merger has the same value, which is $18 \%(0.18)$. So it can be interpreted that after the merger, the net profit margin value did not change, although there was an increase in 2017-2018 but the value of the net profit margin in that year was no better than the value of the net profit margin in 2014 (one year before the merger) .

With these results, it can be said that the ability of PT. Bank Woori Saudara Indonesia 1906, Tbk, after and before the merger did not change in generating the net income from its main operating activities.

\section{Return On Investment (ROI)}

Investors use profitability ratios to be able to measure the returns. One financial measurement tool commonly used to measure the rate of return on investment is the return on investment (ROI) (Wau, Syarifuddin, \& Herwanto, 2017). Paired sample t-test results obtained a significance value (Sig. (2-tailed)) 0.736. Because the significance value is greater than 0.05 $(0.736>0.05)$, it means that there is no significant difference in the ROI variable with a comparison period of 4 (four) years after with 4 (four) years before the merger.

The results of the return on investment data of PT. Bank Woori Saudara Indonesia 1906, Tbk, shows that in 2011-2014 the value of return on investment has decreased from 0.0177 to 0.0084.After the merger from 2015-2018, the value of return on investment increased from 0.0132 to 0.0182 . 
The Effect of Mergers on Financial Performance PT. Bank Woori Saudara Indonesia 1906, Tbk

Maulana, Paramita, Syahiruddin

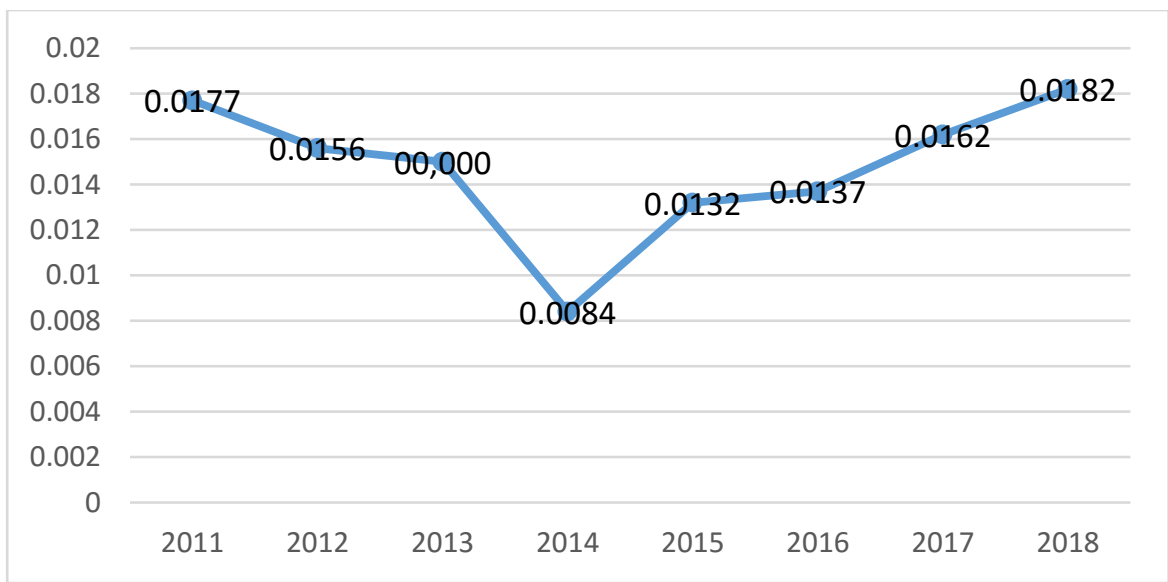

Figure 4. ROI of PT. Bank Woori Saudara Indonesia 1906, Tbk (2011-2018)

The value of return on investment does not increase too large between after and before the merger. But the highest return on investment was in 2018, and the merger also changed the value of return on investment, namely in 2014 when it experienced a very large decline. if seen from the average value of return on investment after and before the merger, the average value of return on investment after the merger has the largest value of 0.0153 . Then it can be interpreted that PT. Bank Woori Saudara Indonesia after the merger is better at managing existing investments (assets), it becomes a profit, even though the profit from before and after the merger does not change too much or its changes are small.

\section{Return On Equity (ROE)}

Ratios Return on Equity (ROE) shows the extent to which companies manage their own capital (net worth) effectively, measure the profitability of the investment that has been made owners of their own capital or shareholders of the company (Heikal et al., 2014 ).

Paired sample t-test results showed a significance value (Sig. (2-tailed)) 0.157 . Because the significance value is greater than $0.05(0.157>0.05)$, it means that there is no significant difference in the ROE variable with a comparison period of 4 (four) years after with 4 (four) years before the merger.

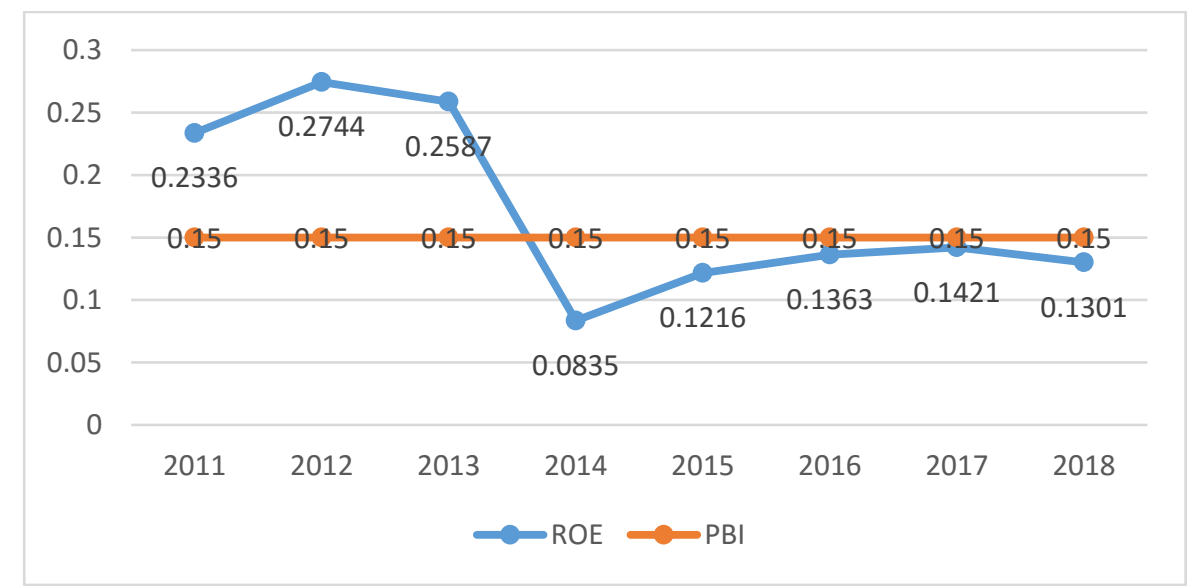

Figure 5. ROE of PT. Bank Woori Saudara Indonesia 1906, Tbk (2011-2018) 
Based on Bank Indonesia's regulations regarding the ranking of return on equity components, the best rate of return on equity is $15 \%(0.15)$. The results of the return on equity data of PT. Bank Woori Saudara Indonesia 1906, Tbk, shows that in 2011-2013 the value of return on equity was at the level of "VERY GOOD". But in 2014 the value of return on equity has decreased, which was at the level of "ENOUGH". After the merger, the value of return on equity in 2012 is still at the level of "ENOUGH". While in 2016-2018 the value of return on equity was increase at the level of "GOOD".

Based on the average value of return on equity, it is found that the average return on equity before the merger is the best, because it is at the level of "VERY GOOD". But that does not mean there is no change after the merger, it is evident that after the merger, return on equity can increase again. the value of return on equity decreased quite high in 2014. Although the increase in return on equity after the merger did not amount to return on equity in 2012. Then the results prove that PT. Bank Woori Saudara Indonesia 1906, Tbk is better in obtaining profits from the available capital after the merger, although it is still not optimal.

\section{Earning Per Share (EPS)}

Earning Per Share is the level of net profit for each share that the company is able to achieve when running its operations (Kholis, Sumarmawati, \& Mutmainah, 2018). Paired sample t-test results showed a significance value (Sig. (2-tailed)) 0.050 . Because the significance value is smaller than $0.05(0.050<0.05)$, it means that there is a significant difference in the EPS variable with a comparison period of 4 (four) years after with 4 (four) years before the merger.

The results of earnings data per share of PT. Bank Woori Saudara Indonesia 1906, Tbk, shows that in 2011-2013 the value of earnings per share was increased. But in 2014 the value of earnings per share was decreased. After the merger from 2015-2018 the value of earnings per share was increased again, and in 2018 is the year where the value of earnings per share was very high.

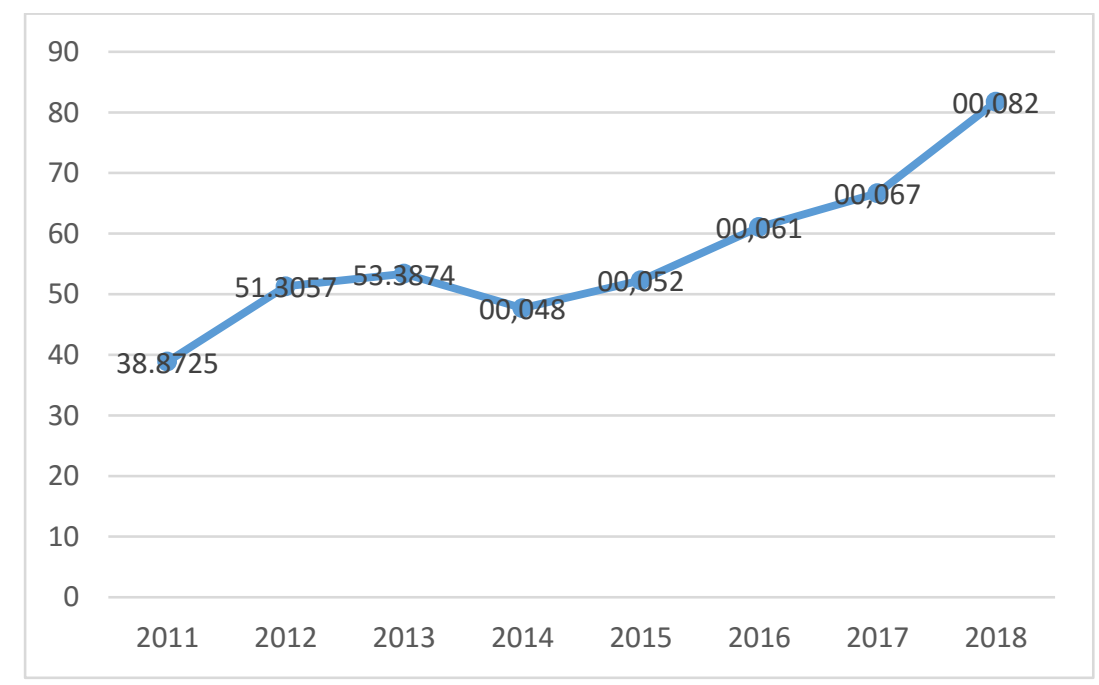

Figure 6. EPS of PT. Bank Woori Saudara Indonesia 1906, Tbk (2011-2018)

Based on the average value of earnings per share after and before the merger, it was found that the average earnings per share after the merger had the highest value. Then these results 
prove that PT. Bank Woori Saudara Indonesia 1906, Tbk after the merger is better in providing benefits to the shareholders of each share they own, compared to before the merger.

Meanwhile, using paired sample t-test with a significance level of $5 \%$, showed that almost all financial ratios after the merger, used in this study, did not experience a significant difference compared to before the merger. But of the seven financial ratios, there are two financial ratios that experienced significant differences after PT. Bank Woori Saudara Indonesia 1906, Tbk conducted a merger, namely the ratio of BR and EPS, but five other financial ratios, did not experience a significant difference between after PT. Bank Woori Saudara Indonesia 1906, Tbk did a merger compared to before the merger. The five ratios are CAR, TATO, NPM, ROI and ROE.

Although there have been changes, these changes have not changed significantly for some financial ratios. Therefore, financial ratios that change but are not significant are considered unchanged or do not differ between before and after the merger.

Of all the ratios used in the study, there are two financial ratios that experience significant differences, but this cannot provide enough evidence that the merger can improve the economic performance of the company. In other words, reject the hypothesis proposed earlier. The results of this study are consistent with previous research, namely Lisa Laiman's research (2017) which examines the analysis of the effects of mergers and acquisitions on financial performance in nonfinancial companies listed on the Indonesia Stock Exchange in the period 2007-2014. In this study the financial ratios used are liquidity ratio, asset management ratio, debt management ratio, profitability ratio, market value ratio and firm size. Based on the results of paired sample t-test shows that only the ratio of assets management ratio, market value ratio, and firm size are significantly different after carrying out mergers and acquisitions.

\section{CONCLUSION}

The liquidity ratio (banking ratio) and the profitability ratio (net profit margin) have decreased after the merger, or in other words the value after the merger is no better than before the merger. While the solvency ratio (capital adequacy ratio), the activity ratio (total asset turnover), the profitability ratio (return on investment and return on equity) and market value ratio (earnings per share) have increased after the merger, or in other words the value after doing merger is better than before merger.

The bank's financial management is already good in managing customer funds channeled (credit), this can be seen from the value of the CAR ratio that increased after the merger. But in returning the customer funds that have been distributed, banks have not been able to return it to the maximum, or it can be said the bank had a bad credit after the merger.

Bank financial management in managing capital generated from buying shares, after the merger can be said to be better than before the merger, this is evidenced by the high EPS value after the merger and where the bank can benefit the shareholders of each share owned.

The Paired Sample T-Test test results for liquidity ratios (banking ratio) and market value ratios (earnings per share) showed a significant difference between before and after the merger. While the solvency ratio (capital adequacy ratio), activity ratio (total asset turnover), and profitability ratio (net profit margin, return on investment, and return on equity) show no significant difference between before and after the merger. But from the significant change between the two ratios, only the EPS ratio illustrates that the financial performance of PT. Bank Woori Saudara Indonesia 1906, Tbk can be said to be good. 
Companies that will conduct a merger should see the condition of their company, both from the company's management and the company's finances. Because based on the results of this study, the merger did not show a significant difference to the company's financial performance. So that the company's management must really take into account, whether the merger will be in accordance with the objectives to be achieved by the company.

For the investors, information before and after the merger is very important, because it can affect the stock prices, so investors should look for more accurate information because it can be used as a reference to find out how much profit will be obtained.

For the future researchers, it is better to add the research variables such as the other financial ratios, and it is better to increase the observation period to be longer, so as to improve the quality of research results. This study analyzes the company performance based on economic factors only (financial), but there may be other non-economic factors that can be measured to see the impact of merger activities on improving company performance such as technology, human resources, taxes, corporate culture, and others.

\section{REFERENCE}

Ahmed, F., Manwani, A., \& Ahmed, S. (2018). Merger \& acquisition strategy for growth, improved performance and survival in the financial sector. Jurnal Perspektif Pembiayaan Dan Pembangunan Daerah, 5(4), 196-214. https://doi.org/10.22437/ppd.v5i4.5010

Heikal, M., Khaddafi, M., \& Ummah, A. (2014). Influence Analysis of Return on Assets (ROA), Return on Equity (ROE), Net Profit Margin (NPM), Debt To Equity Ratio (DER), and current ratio (CR), Against Corporate Profit Growth In Automotive In Indonesia Stock Exchange. International Journal of Academic Research in Business and Social Sciences, 4(12), 101-114. https://doi.org/10.6007/ijarbss/v4-i12/1331

Heykal, M., \& Hennisia, M. W. (2015). Analisis Hubungan antara Merger dan Akuisisi Terhadap Kinerja Keuangan dan Return Saham pada Perbankan yang Terdaftar Di BEI. Politeknik Negeri Jakarta, 1(3), 178-186. Retrieved from http://akuntansi.pnj.ac.id/upload/artikel/files/Mohammad Heykal, Monica Hennisia Wijayanti.pdf

Juniarti. (2001). Contemporary Theory Sebagai Pendekatan Alternatif Dalam Penyusunan Laporan Konsolidasi. Jurnal Akuntansi Dan Keuangan, 3(1), 1-17. https://doi.org/10.9744/jak.3.1.pp.1-17

Kemal, M. U. (2011). Post-Merger Profitability : A Case of Royal Bank of Scotland ( RBS ). International Journal of Business and Social Science, 2(5), 157-162. Retrieved from http://ijbssnet.com/view.php?u=http://ijbssnet.com/journals/Vol._2_No._5_[Special_Iss ue_-_March_2011]/20.pdf

Kholis, N. K., Sumarmawati, E. D., \& Mutmainah, H. M. (2018). Faktor-Faktor Yang Mempengaruhi Nilai Perusahaan. Jurnal Analisis Bisnis Ekonomi, 16(1), 19-25. https://doi.org/10.31603/bisnisekonomi.v16i1.2127

Mahesh, R., \& Prasad, D. (2012). Post Merger and Acquisition of Financial Performance Analysis: A Case Study of Select Indian Airline Companies. International Journal of Engineering and Management Sciences, 3(3), 362-369.

Sofyan, M. (2019). Faktor-Faktor Yang Mempengaruhi Profitabilitas Bank Perkreditan Rakyat (BPR) di Provinsi Jawa Timur. Jurnal Inspirasi Bisnis Dan Manajemen, 3(1), 63-76. Retrieved from http://jurnal.unswagati.ac.id/index.php/jibm/article/view/2093 
Tarigan, P., \& Pratomo, W. (2015). Analisis Dampak Merger dan Akuisisi Terhadap Abnormal Return dan Kinerja Keuangan Pada Perusahaan yang Terdaftar di Bursa Efek Indonesia. Jurnal Ekonomi Dan Keuangan, 3(3), 200-2012. Retrieved from https://media.neliti.com/media/publications/147945-ID-none.pdf

Tugas, F. C. (2012). A Comparative Analysis of the Financial Ratios of Listed Firms Belonging to the Education Subsector in the Philippines for the Years 2009-2011. International Journal of Business and Social Science, 3(21), 173-190. Retrieved from http://ijbssnet.com/journals/Vol_3_No_21_November_2012/19.pdf

Wau, R., Syarifuddin, A., \& Herwanto, R. (2017). Analisis Perbandingan Economic Value Added (EVA) dan Return On Investment (ROI) Dalam Menilai Kinerja Keuangn Sub Sektor Farmasi yang Terdapat di Bursa Efek Indonesia. Business Studies, 2(1), 99-110. Retrieved from http://journal.uta45jakarta.ac.id/index.php/jbsuta/article/view/790/508

Yanan, E. M., Hamza, S. M., \& Basit, A. (2016). Impact of Merger and Acquisitions on Firms Financial Performance : A Study on United States of America. International Journal of Accounting \& Business Management. https://doi.org/10.24924/ijabm/2016.11/v4.iss2/159.169 